\title{
THE SUBTLE INTERPLAY OF COMPETING SUBJECTIVE NORMS, AFFINITY AND ANIMOSITY IN CONSUMER AVERSION OR INCLINATION TO FOREIGN GOODS
}

\author{
*Aysel ERCIS (Orcid Id: 0000-0002-9835-8574) \\ **Bilal CELIK (Orcid Id: 0000-0001-6253-3177) \\ *Atatürk University, Turkey \\ **Bayburt University. Turkey
}

\begin{abstract}
This paper investigates the interplay between subjective norms, affinity and animosity in consumers' foreign products judgement and willingness to buy. The data was collected with a survey and sample consisting of 271 participants. Structural equation modelling (SEM) using AMOS 20.0 was applied in order to analyse the data. The results revealed that there is a relationships between consumer affinity and product judgement but there is no relationships between consumer affinity and willingness to buy. It also found out that subjective norms are related to affinity but not related to animosity and subjective norms have effects on products judgement but have no any effects on willingness to buy. Animosity also has effects on willingness to buy but not with related to product judgement. This research paper recommended that beside animosity, other components such as affinity and subjective norms impact consumer decision-making. Thus, such kinds of emotional bonds and other biases with foreign countries and norms need to be examined by academicians in intra and international contexts to understand how consumer make a decision and how they influenced by such dispositions or biases.
\end{abstract}

Keywords: Subjective Norms; Affinity; Animosity; Decision-Making

\section{INTRODUCTION}

Many past and recent studies show that consumers' decision making influenced by not only quality or price of a product but also other emotional or cognitive factors have effects on consumers' decision making. "It is well documented that consumers' product evaluations, preferences, and buying intentions are not solely based on product cues such as price, brand name, or quality, but that feelings also affect consumption decisions" (Oberecker and Diamantopoulos 2011; Batra and Holbrook 1990; Holbrook and Hirschman 1982). In international marketing context, consumers are not only motivated by economic concerns but they are also motivated by positive or negative feelings toward a particular country (Oberecker and Diamantopoulos 2011; Riefler and Diamantopoulos 2007; Verlegh 2007). Bahaee and Pisani (2009), for example, found out that Iranian consumers' animosity for the USA spring from a US law which prohibits the existence of US products and business in Iran.

It is thus many researches have been focused on unfavourable attitudes of consumers towards foreign countries such as consumer animosity (Oberecker, Riefler, and Diamantopoulos 2008; Klein, Ettenson, and Morris 1998), consumer ethnocentrism (Oberecker, Riefler, and Diamantopoulos 2008; Shimp and Sharma, 1987). However, limited researches have concentrated on favourable attitudes of consumers toward foreign countries that can cause to intentionally purchase of foreign products in the marketing literature (Oberecker and Diamantopoulos 2011; e.g., Brijs et al. 2006; Jaffe and Nebenzahl 2006; Verlegh 2001). Hence, according to Oberecker and Diamantopoulos (2011) it is important to make a research on that topic because underlying feelings can be helpful in order to understand why local consumers prefer to buy foreign products or why they do not prefer to buy foreign products (Oberecker and Diamantopoulos 2011).

Previous studies basically examined the animosity towards a specific country (Suhud, 2018), and other research based on consumer affinity for foreign countries and animosity contrast (Nes et al. 2014), however, they have not involved the importance of subjective norms and also the effects of the relationships between affinity, animosity and subjective norms on consumer decision making have not been examined in these research.

Researchers also found out that there is a link between the cultural identification of young transnational Chinese consumers and animosity and it was explained as mechanism underlying animosity towards Japanese products (Yang et al. 2015). The purpose of this research, thus, from this background, is to explore the effects 
of the relationships between consumer affinity, consumer animosity and subjective norms on consumers' foreign products judgements and willingness to buy foreign products. Contextualized in the recent territorial dispute, in this regard, this research examines consumer affinity, animosity and subjective norms from the perspective of young consumers towards American made products. Since, it is important to understand how consumer behave and to develop some strategic recommendations for managers for such cases.

\section{LITERATURE REVIEW AND THEORETICAL FRAMEWORK}

Previous studies have revealed that consumer product beliefs (Maher and Mady, 2009; Heslop et al., 2004 and Papadopoulos Heslop, 2003), product evaluations (Maher and Mady, 2009; Heslop et al., 2004; Knight and Calantone, 2000), and willingness to buy (Maher and Mady, 2009; Wang and Lamb, 1980) are affected by cognitions of another country. Thus, in this section, the constructs relating with the consumer behaviour which are called; consumer animosity, consumer affinity and also subjective norms will be reviewed based on the purpose of the research.

\section{Subjective Norms (SN)}

Subjective norms (SN) are related to the perceived social pressure and influences to perform or not to perform in a given behaviour (Al-Swidi et all, 2014; O’Neal, 2007; Ajzen, 1991). One another previous research relating with the subjective norms and animosity has revealed that "a product's country of origin will have a normative impact when social norms dictate the desirability of purchasing products based on country of origin (COO). For example, even if a consumer holds positive perceptions of foreign products, social norms might dictate that the purchase of foreign products might be deemed "Un-American" such normative impact has typically been captured in country of origin (COO) studies using consumer ethnocentrism." (Maher and Mady, 2009). It was furthermore argued that in a collective culture as Kuwait, the effects of social norms is a significant point in order to understand consumer behaviour in that consumers in such collective culture care about how other people take their behavior into consideration (Maher and Mady, 2010). Another research also shown that subjective norms have effects more on predicting consumer behaviour intentions rather than attitudes in collectivist societies (Maher and Mady, 2010; Lee and Green, 1991). Based on previous studies, moreover, students who moved to a cosmopolitan cities are more independent rather than those who moved to a non-cosmopolitan cities or never moved to anywhere (Sevincer at al., 2015). Thus, such kinds of small cities are lower cosmopolitan compared to other big cities and the effects of subjective norms might be higher than in big cities. Accordingly, it is claimed that Turkey is a collectivist culture and consumers are concerned about what others think about them while they are consuming, particularly in small cities that are lower cosmopolitan. For this, it is important to examine the effects of subjective norms on not only consumers' emotional bonds with foreign countries like consumer animosity and consumer affinity but also foreign product judgements and willingness to buy foreign product. Thus, based on these explanations the following hypothesis proposed that;

H1a: Subjective norms will be negatively associated with consumer affinity towards a country.
H1b: Subjective norms will be positively associated with consumer animosity towards a country.
H1c: Subjective norms will be negatively associated with judgement of products from a foreign country.
H1d: Subjective norms will be negatively associated with willingness to buy products from a foreign country.

\section{Consumer Affinity (CAf)}

Cognitive factors such as country beliefs or negative attitudes such as animosity have recognised in past researches generally and because of this tendency the role of positive attitudes or beliefs have been neglected (Toffoli, et al. 2015). Therefore, in order to close this gap, Oberecker and Diamantopoulos (2011) proposed the term "consumer affinity" (CAf) construct which explains consumers' positive emotions for a specific foreign country have effects on consumer buying decision (Toffoli, et al. 2015).

The term "consumer affinity" is defined as; "A feeling of liking, sympathy, and even attachment toward a specific foreign country that has become an in-group as a result of the consumer's direct personal experience and/or normative exposure and that positively affects the consumer's decision making associated with products and services originating from the affinity country." (Oberecker, Riefler, and Diamantopoulos, 2008, p. 26 emphasis added).

According to Oberecker et al. (2008) conceptualization of affinity springs up from the social identity theory and distinction between in-groups and out-groups. Extensively, favouritism of the in-group consider in the marketing literature (Oberecker, Riefler, and Diamantopoulos, 2008; Ashforth and Mael, 1989), and consumer ethnocentrism is an example of in-group bias (Oberecker, Riefler, and Diamantopoulos, 2008, Shimp and 
Sharma, 1987). Notwithstanding, it is recommended that in social-psychological literature, people are not only negatively biased to all out-groups (Oberecker, Riefler, and Diamantopoulos, 2008; Brewer, 1979) but they are positively towards specific out-groups as well (Oberecker, Riefler, and Diamantopoulos, 2008; Druckman, 1994). Within this framework, people can feel more attachment, sympathy and admiration toward specific outgroups (other nations) (Oberecker, Riefler, and Diamantopoulos, 2008).

To the attitude theory, attitude might be described as "a learned predisposition to respond in a consistently favourable or unfavourable manner with respect to a given object" (Fishbein and Ajzen 1975, p. 6). With regard to this, consumer affinity is examined a favourable and pre-emptively affectively based attitude (Lutz, 1981) and this attitude can influence on consumer behaviour toward a focal foreign country and could be seen in intentions to consume products, services and brands from the affinity country as a result of this behavioural consequences (Oberecker, Riefler, and Diamantopoulos, 2008). It is thus the following hypothesis proposed that;

\section{H2a: Consumer affinity towards a country will be positively associated with the judgments of products from that country}

\section{H2b: Consumer affinity towards a country will be positively associated with the willingness to buy products from that country.}

\section{Consumer Animosity (CAn)}

In the marketing literature, animosity is described as "the remnants of antipathy related to previous or ongoing military, political, or economic events" (Klein et al., 1998, p. 90). In other words, consumer animosity is described as the hostility felt toward a specific national origin of a good/product (Cakici and Shukla, 2017; Riefler and Diamantopoulos, 2007). In recent years, on the effects of consumer animosity on consumers' decision making and perception of products perpetrators' country of origin have been received in many researches (Ettenson and Klein, 2005; Klein et al., 1998; Klein, 2002; Nijssen and Douglas, 2004; Maher and Mady, 2010). As a typical example of this, in the South Pacific, French recently tested nuclear bomb and so Australian consumers illustrated animosity against French (Ettenson and Klein, 2005 Maher and Mady, 2010). It is thus, consumer animosity has been a really important topic to discuss in the marketing literature. However, the effects of the relationships between consumer animosity, consumer affinity and subjective norms have not fully included in previous researches.

A typology that has been developed by Jung et al. (2002) and Ang et al. (2004) categorizes animosity based on its sources and locus. It has been distinguished between stable and situational animosity based on the sources of animosity and also has been defined according to the locus of manifestation, national and personal animosity (Ang et al. 2004). The stable animosity is driven by historical events such as military or economics antagonism between countries, whilst the situational animosity is motivated by a specific event. However, it can evolve from the situational animosity to the stable animosity over time toward a particular country (Perviz et al. 2014). In a study, Ettenson and Klein (2005) examined Australian consumers' animosity toward French at two points in time. The first measurement was conducted during nuclear testing by French in the South Pacific and the second measurement was conducted after one year. As a result of these measurements, the existence of situational animosity has been confirmed and it was also confirmed that animosity is a dynamic concept because it was observed that the level of animosity was lower in the second Ettenson and Klein (2005). As mentioned, Ettenson and Klein (2005) defined the animosity as national animosity at the macro level and personal animosity at the micro level. As reported by Rose et al. (2009) there is no link between consumer animosity and judgement of product quality. Nevertheless, as stated in another research, there is a negative link between consumer animosity associated with and product judgement of domestically made products across subcultures within a specific nation (Rose et al., 2009; Shoham et al., 2006).

They recommended that the findings might be resulted from the use of goods and services that are made domestically as such goods and services cannot be explained separately from the culture (Rose et al., 2009; Shoham et al., 2006). It was, however, claimed that these findings might be explained by the other conceptual differences (Rose et al., 2009). Moving from these explanations, thus, the following hypothesis proposed that;

\section{H3a: Consumer animosity towards a country will be negatively associated with the judgment of products} from that country.

H3b: Consumer animosity towards a country will be negatively associated with the willingness to buy products from that country. 
Figure 1. The conceptual model

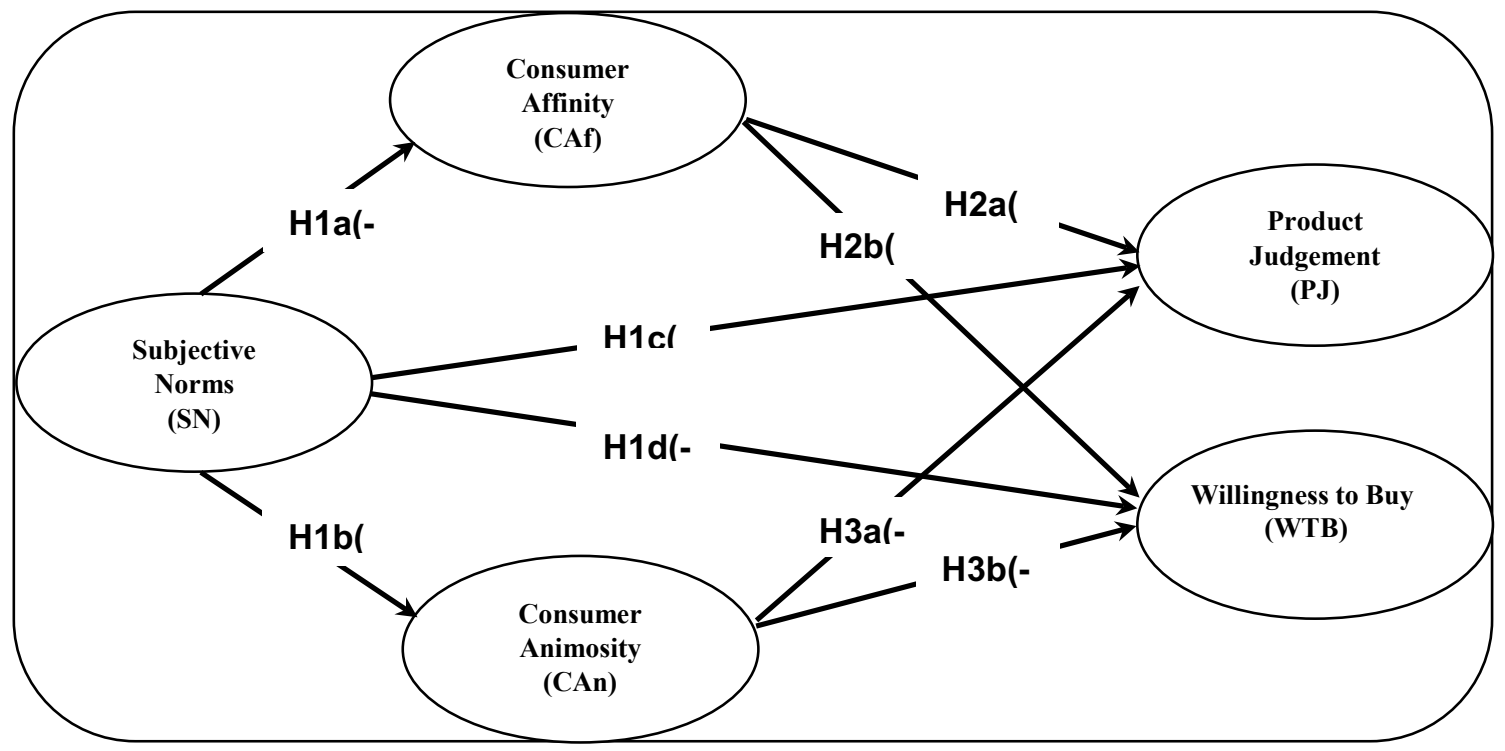

\section{RESEARCH METHOD}

\section{Sample and Data Collection}

The data was collected during January and February of 2019 in Bayburt, the city was chosen as it is the smallest city in Turkey. As mentioned, based on previous research, students who moved to a cosmopolitan cities are more independent rather than those who moved to a non-cosmopolitan cities or never moved to anywhere (Sevincer at al., 2015). So, these kinds of small cities are lower cosmopolitan and in such a small cities, the effects of subjective norms higher than in big cities. In order to collect the data, simple random sampling (SRS) was implemented since it is a basic sampling method and give an equal opportunity for every possible case of size $\mathrm{n}$, which come from a population of size $\mathrm{N}$, thus, and in such a way that every possible simple of size has an equal chance to be selected (Meng, 2013). In total, 275 respondents participated in survey, but, 4 of the questionnaire have been eliminated due to missing data and finally there were 271 analysed. 55.4 $\%$ of the participants were female while, $44.6 \%$ were male. This research mainly focused on the effects of the relationships between animosity, affinity and subjective norms on young consumers' foreign products judgement and purchasing behaviour. Thus, the sample included predominantly young participants $93.4 \%$ within age group between 18 and 25 , the monthly income of the vast majority of participants $83.4 \%$ were from 1301 to $2000 \mathrm{TL}$. These data means that the procedures fulfilled the aim of the research.

\section{Analyses}

To analyse the data, consumer animosity and affinity scales were adopted from Wongtada et al. (2012) and for the consumer animosity 4 items and for the consumer affinity 17 items were used. These items uses to analyse general Personal Stable Animosity (General Animosity) and People Affinity, Technology and Innovation Affinity (Technology Affinity) and Business Achievement (Business Affinity). The research does not include National Stable Animosity (general animosity, economic animosity, political animosity) and Scenery and Infrastructure Affinity, Education Affinity this is because of the purpose of the research. The scale of subjective norms was adopted from Lee and Green (1991) and 4 items were used. The scale of the product judgment and the willingness to purchase were adopted from Riefler and Diamantopoulos (2007) and for the product judgement 5 items and for willingness to buy foreign product 6 items were used. Totally, 36 items were used for the purpose of the research. The questionnaires were first translated from English into Turkish. To translate the questionnaires the "Back Translation Technique" was used. The "Back Translation", which is a process of translating the documents commonly used to check the accuracy of translation in survey research (Douglas and Craig, 2007). After that the pre-test was done to eliminate the problems caused by language differences to make the questionnaires more understandable. After the pre-test, the problems caused by language differences were eliminated, and the questionnaire was started to be applied on the selected sample. The Likert-scale with the " $1=$ Strongly Disagree" to " $5=$ Strongly Agree" type was used to measure the items. 


\section{FINDINGS}

The data was analysed using AMOS 20.0 pocket program and Structural Equation Model (SEM) was performed in line with the purpose of the study. To analyse the model fit, Confirmatory Factor Analysis (CFA) was implemented first of all. After that the hypotheses were analysed. The CFA results revealed that $\left(\chi^{2}=\right.$ 433.858, $\mathrm{df}=235, \chi^{2} / \mathrm{df}=1.846, \mathrm{p}<0.001, \mathrm{GFI}=0.883, \mathrm{CFI}=0.926$, TLI $=0.913$, RMSEA $\left.=0.056\right)$ with reference to the previous study by Hair et al. (2006) recommended that CFI can be 0.92 or greater and RMSEA might be 0.07 or less. Also, the following results obtained, which might be seen below Table 1, supported by the literature (Erdogan, Aydın and Kirmizi, 2019; Meydan and Şeşen, 2015; Uğurlu, 2014; Kline, 2005; Cole, 1987). Accordingly, measurements items are reliability and validity. After the CFA, the proposed model of the research was tested as seen below Figure 2 .

Table 1. CFA Compliance Values

\begin{tabular}{ccc}
\hline Indices & Value & Acceptable fit \\
\hline Chi-Square $\left(\chi^{2}\right)$ & $\mathbf{4 3 3 . 8 5 8}$ & \\
df & $\mathbf{2 3 5}$ & $\chi^{2} \leq \mathbf{5}$ \\
$\left(\chi^{2}\right) /$ df & $\mathbf{1 . 8 4 6}$ & $\mathbf{0 . 0 5} \leq \mathbf{R M S E A} \leq \mathbf{0 . 0 8}$ \\
RMSEA & 0.056 & $\mathbf{0 , 8 0} \leq$ NFI $\leq \mathbf{0 , 9 5}$ \\
NFI & $\mathbf{0 . 8 5 3}$ & $\mathbf{0 . 9 0} \leq \mathbf{C F I} \leq \mathbf{0 . 9 7}$ \\
CFI & $\mathbf{0 . 9 2 6}$ & $\mathbf{0 . 8 0} \leq$ GFI $\leq \mathbf{0 , 9 5}$ \\
GFI & $\mathbf{0 . 8 8 3}$ & \\
\hline
\end{tabular}

Figure 2: Assessment of Structural Model

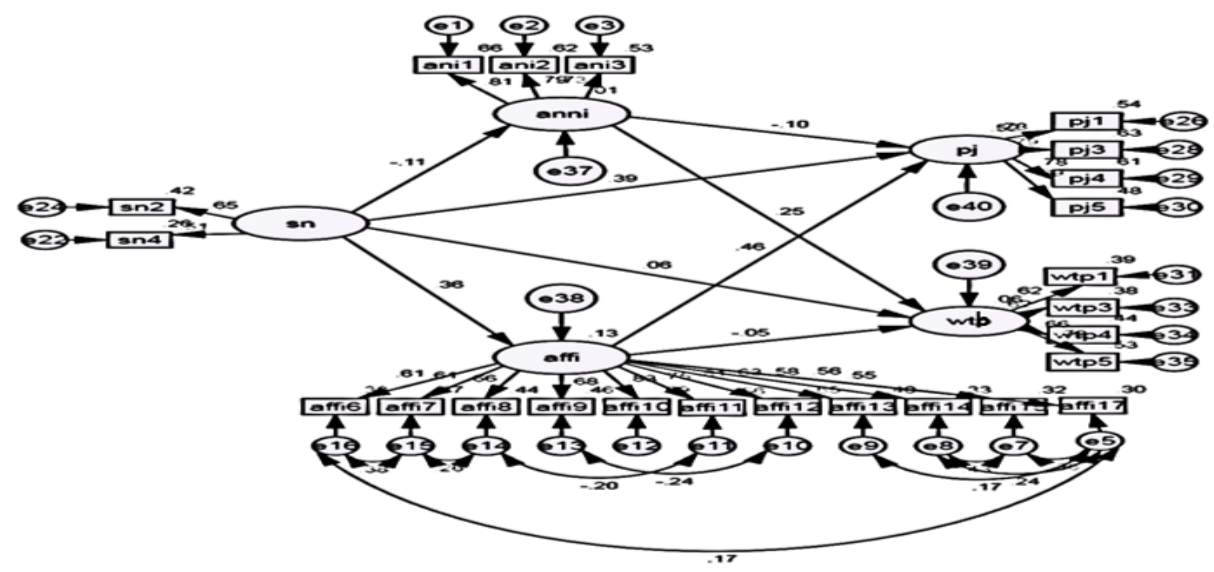

Table 1: Summary of Hypotheses Test Results

\begin{tabular}{|c|c|c|c|c|}
\hline $\begin{array}{l}\text { Hypothesis } \\
\text { No. }\end{array}$ & Structural Path & $\begin{array}{c}\text { Standardized } \\
\text { Regression } \\
\text { Weight }(\beta) \\
\end{array}$ & $\begin{array}{c}\text { Critical } \\
\text { Ratio (C.R.) }\end{array}$ & Result \\
\hline H1a & $\mathrm{SN} \rightarrow \mathrm{CAf}$ & .355 & $3.280^{*}$ & Supported \\
\hline $\mathrm{H} 1 \mathrm{~b}$ & $\mathrm{SN} \rightarrow \mathrm{CAn}$ & -.114 & -1.2383 & Not Supported \\
\hline $\mathrm{H} 1 \mathrm{c}$ & $\mathrm{SN} \rightarrow \mathrm{PJ}$ & .389 & $3.602 * *$ & Supported \\
\hline H1d & $\mathrm{SN} \rightarrow \mathrm{WTB}$ & .065 & .628 & Not Supported \\
\hline $\mathrm{H} 2 \mathrm{~b}$ & $\mathrm{CAf} \rightarrow \mathrm{PJ}$ & .463 & $5.395 * *$ & Supported \\
\hline $\mathrm{H} 2 \mathrm{a}$ & CAf $\rightarrow$ WTB & -.054 & .662 & Not Supported \\
\hline $\mathrm{H} 3 \mathrm{a}$ & $\mathrm{CAn} \rightarrow \mathrm{PJ}$ & -.101 & -1.626 & Not Supported \\
\hline $\mathrm{H} 3 \mathrm{~b}$ & CAn $\rightarrow$ WTB & .246 & $3.064 *$ & Supported \\
\hline
\end{tabular}




\section{CONCLUSION AND DISCUSSIONS}

The findings of previous researches revealed that there is a positive correlations between consumer affinity and product judgement in intra and international contexts and consumer affinity stronger than consumer animosity in terms of product judgement however not with respect to willingness to buy (Asseraf and Shoham, 2016). The findings of this study also supported the previous findings that consumer affinity correlates positively with product judgement. Unlike previous studies, the impact of subjective norms on consumer affinity and animosity were analysed in this research to understand consumers' foreign product judgements and willingness to buy in more detail. The (H1a), which has been supported by the results stated that the subjective norms is negatively related to consumer affinity. Subjective norms have effects on consumer affinity particularly in small cities which are lower cosmopolitan and not totally open for new experiences as mentioned. Thus, this argument supported by the results because this study was carried out in a small city. However, it is one of the reason but not enough to explain affinity construct totally. Thus, these results should be explained in detail in order to understand consumer behavior. The ( $\mathrm{H} 1 \mathrm{~b})$, which has not been supported by the results, proposed that subjective norms is positively related to consumer animosity. The research findings of Akdogan et al. (2012) explained that consumer animosity influence consumer willingness to buy foreign products and they also mentioned consumer animosity have negative effects on consumer re-purchase intention of foreign products. Also, our finding that coincide with previous findings that the consumer animosity is negatively related to willingness to buy foreign products. However the results revealed that consumer animosity is not related to product judgement, as reported by Rose et al. (2009) there is no link between consumer animosity and judgement of product quality.

Maher and Mady (2010), in their research, found out the negative relationship between subjective norms and willingness to buy however the results of this research did not support this argument. Interestingly, the results showed that there is a relationships between subjective norms and foreign product judgement. It explains that consumers are influenced by subjective norms in terms of product judgement however, they still prefer to buy foreign product. It may also means that consumers who live in small and less cosmopolitan places do not hesitate to buy what they want as a result, even if they pay attention to what others think of themselves. Personal characteristics and/or personal expectations and preferences can exceed the expectations of the environment.

It is suggested that human dispositions that can influence consumer choices in diverse purchasing situations should not be ignored by companies and particularly multinational companies in order to overcome the complex problems. As, competitions are tough in international markets therefore, marketers should take into considerations such kinds of dispositions when they develop marketing strategies to enter an international market. Furthermore, Consumer preferences and choices are influenced by personality and culture traits and because of their important role on consumer decision making marketers should pay attention on such variables (Leonidou, et al. 2019) to compete with competitor and successful in international markets and increase their marketing performance. It is also discussed that the effects of affinity on demand merits investments in nation branding (Nes et al., 2014; Kotler and Gertner, 2002). Thus, nation can compete by using affinity construct in attracting tourist and factories for the exports and developing consumer affinity can contribute the nation brand equity finally.

Regarding the future research, the interplay of competing consumers' emotional bonds with foreign countries like subjective norms, affinity, and animosity and also other variables such as ethnocentrism, national-global consumer identity that play an important role in consumer behaviour should be examined in further researches. Personality traits need also be assessed in this context because a few studies of this type have interestingly included personal characteristics among other components. Because of that there is a gap in marketing literature and researchers need to focus on this gap. The moderating role of cultural intelligence should also be tested in this conceptual model to understand the effect of these kinds of components of consumer behaviour or emotional bonds with foreign countries on consumer decision making. Nes et al. (2014) claimed that consumer affinity is associated with actual product ownership however, the relationship between affinity and actual product ownership has not been examined in this research. It is another important point that is need to be assessed in future research with other components. 


\section{REFERENCES}

Abdullah Al-Swidi, Sheikh Mohammed Rafiul Huque, Muhammad Haroon Hafeez and Mohd Noor Mohd Shariff, (2014). The role of subjective norms in theory of planned behavior in the context of organic food consumption, British Food Journal, 116 (10), 1561 - 1580.

Ajzen, I. (1991). The theory of planned behavior, Organizational Behavior and Human Decision Processes, 50(2), 179-211.

Akdogan, M.S., Kaplan, M., Ozgener, S. and Coskun, A. (2012). The effects of consumer ethnocentrism and consumer animosity on the re-purchase intent: The moderating role of consumer loyalty. Emerging Markets Journal, 2(1), 1-12.

Ashforth, Blake E. and Fred Mael (1989) Social Identity Theory and the Organization, Academy of Management Review, 1, 4 (1), 20-35.

Bahaee, M. and Pisani, M.J. (2009), Iranian consumer animosity and US products: a witch's brew or elixir? International Business Review 18(2):199-210

Batra, Rajeev and Morris B. Holbrook (1990). Developing a Typology of Affective Responses to Advertising, Psychology and Marketing, 7 (1), 11-25.

Brewer, Marilynn B. (1979). In-Group Bias in the Minimal Intergroup Situation: A Cognitive-Motivational Analysis, Psychological Bulletin, 86 (2), 307-324.

Cakici, N. Meltem and Shukla, Paurav (2017). Country-of-origin misclassification awareness and consumers' behavioral intentions: Moderating roles of consumer affinity, animosity, and product knowledge, International Marketing Review, DOI: 10.1108/IMR-08-2015-0178.

Cole, D.A. (1987). Utility of confirmatory factor analysis in test validation research. Journal of Consulting and Clinical Psychology, 55, 1019-1031.

Druckman, Daniel (1994). Nationalism, Patriotism, and Group Loyalty: A Social Psychological Perspective. Mershon International Studies Review, 38 (1), 43-68.

Erdogan, Z. B., Aydın, B. and Kirmizi, D. (2019). Which Is The Moderator Of Ethnocentrism: Country Or Product Image? Tourism, Leisure and Global Change, 5, p. 162-178.

Ettenson, R. and Klein, J.G. (2005). The fallout from French nuclear testing in the South Pacific -a longitudinal study of consumer boycotts. International Marketing Review, 22(2), 199-224.

Fishbein, Martin and Icek Ajzen (1975). Attitude, Intention and Behavior: An Introduction to Theory and Research. Reading, MA: Addison-Wesley.

Hair, J., Black, W.C., Babin, B.J., Anderson, R.E. and Tatham, R.L. (2006), Multivariate Data Analysis, 6th ed., Prentice-Hall, Englewood Cliffs, NJ.

Heslop, L.A., Papadopoulos, N., Dowdles, M., Wall, M. and Compeau, D. (2004). Who controls the purse strings: a study of consumers' and retail buyers' reactions in an America's FTA environment. Journal of Business Research, 57(10), 1177-88.

Jung, K., Ang, S.H., Leong, S.M., Tan, S.J., Pornpitakpan, C., \& Kau, A.K. (2002). A typology of animosity and its cross-national validation. Journal of Cross-Cultural Psychology, 33 (6), 525-539.

Klein, J.G., Ettenson, R. and Morris, M.D. (1998). The animosity model of foreign product purchase: an empirical test in the People's Republic of China. Journal of Marketing, 62(1), 89-100.

Klein, Jill G., Richard Ettenson, and Marlene D. Morris (1998). The Animosity Model of Foreign Product Purchase: An Empirical Test in the People's Republic of China. Journal of Marketing, 62, 89-100.

Kline, R. B. (2005). Principles and practice of structural equation modelling (2. bask1). New York: The Guilford Press.

Knight, G.A. and Calantone, R.J. (2000). A flexible model of consumer country-of-origin perceptions. International Marketing Review, 17 (2/3), 127.

Kotler, P., \& Gertner, D. (2002). Country as brand, product, and beyond: A place marketing and brand management perspective, Journal of Brand Management, 9, 249-261.

Lee, C. and Green, R.T. (1991). Cross-cultural examination of the Fishbein behavioral intentions model. Journal of International Business Studies, 22(2), 289-305.

Lejla Perviz, Tina Geč, Irena Vida, Tanja Dmitrović (2014). The Origins and Consequences of Consumer Animosity in Slovenia: A Qualitative Study. Economic and Business Review, 16(2), 133-161 
Leonidou, Leonidas, Kvasova, Olga, Christodoulides, Paul, Tokar, Sergii (2019). Personality Traits, Consumer Animosity, and Foreign Product Avoidance: The Moderating Role of Individual Cultural Characteristics. Journal of International Marketing, 27(2), 1-21

Lutz, R.J., (1981). The Role of Attitude Theory In Marketing. In Perspectives in Consumer Behavior, Third Edition, Kassarjian, H.H., and Robertson, T.S. (eds.), Englewood Cliffs, NJ: Scott Foresman, 233-50.

Maher, Amro A. and Mady S. (2010). Animosity, subjective norms, and anticipated emotions during an international crisis. International Marketing Review, Vol. 27 No. 6, 630-651

Meng, X. (2013). Scalable simple random sampling and stratified sampling. Proceedings of the 30th. International Conference on Machine Learning, Atlanta, Georgia, USA, 2013. JMLR: W\&CP volume 28. Copyright 2013 by the author(s).

Meydan, C. H. \& Şeşen, H., (2015). Yapısal eşitlik modellemesi AMOS uygulamaları. 2. Baskı, Ankara, Detay Yayıncilık.

Morris B. Holbrook and Elizabeth C. Hirschman (1982). The Experiential Aspects of Consumption: Consumer Fantasies, Feelings, and Fun. Journal of Consumer Research, 9 (2), 132-40.

Nes, E.B., Yelkur, R., and Silkoset, R., (2014) Consumer affinity for foreign countries: Construct development, buying behaviour consequences and animosity contrast. International Business Review, 23, 774-784.

Nittaya Wongtada, Gillian Rice \& Subir K. Bandyopadhyay (2012) Developing and Validating AFFINITY: A New Scale to Measure Consumer Affinity toward Foreign Countries, Journal of International Consumer Marketing, 24:3, 147-167.

Oberecker, Eva M., Petra Riefler, and Adamantios Diamantopoulos (2008). The Consumer Affinity Construct: Conceptualization, Qualitative Investigation, and Research Agenda. Journal of International Marketing, 16 (3), 23-56. or elixir? International Business Review, 18:2, 199-210.

Papadopoulos, N. and Heslop, L.A. (2003). Country equity and product-country images: state-of-the-art in research and implications. In Jain, S.C. (Ed.), Handbook of Research in International Marketing, Cheltenham, Northampton, 402-33.

Qinghua Yang, Katy Snell \& Wanhsiu Sunny Tsai (2015) Understanding Consumer Animosity in the Politicized Global Market: From the Perspective of Young Transnational Consumers, Journal of International Consumer Marketing, 27(3), 220-236.

Riefler, Petra and Adamantios Diamantopoulos (2007). Consumer Animosity: A Literature Review and a Reconsideration of Its Measurement. International Marketing Review, 24 (1), 87-119.

Rose, M., Rose, G. M., \& Shoham, A. (2009). The impact of consumer animosity on attitudes towards foreign goods: A study of Jewish and Arab Israelis. Journal of Consumer Marketing, 26(5), 330-339.

Sevincer AT, Kitayama S and Varnum MEW (2015) Cosmopolitan cities: the frontier in the twenty-first century? Front. Psychol. 6:1459. Doi: 10.3389/fpsyg.2015.01459

Shimp, Terence A. and Subhash Sharma (1987). Consumer Ethnocentrism: Construction and Validation of the CETSCALE. Journal of Marketing Research, 24, 280-89.

Shoham, A., Davidow, M., Klein, J.G. and Ruvio, A. (2006). Animosity on the home front: the intifada in Israel and its impact on consumer behavior. Journal of International Marketing, 14:3, 92-114.

Suhud, U. (2018). The Impact of Consumer Animosity on Purchase Unwillingness in a Boycott of Sari Roti. Binus Business Review, 9(2), 87-94.

Susan P. Douglas and C. Samuel Craig (2007) Collaborative and Iterative Translation: An Alternative Approach to Back Translation. Journal of International Marketing, Vol. 15, No. 1 (2007), pp. 30-43

Toffoli, et al. (2015). Impact of Acculturation, Consumer Affinity, and Inverse COO Effect on a Supplier Country's Image from Exporting Professional Services to a Host Country: A Conceptual Framework" International Marketing in the Fast Changing World Advances in International Marketing, 26, 199-233.

Uğurlu, C. T. (2014). İnformal iletişim ölçeği geçerlik ve güvenirlik çalışması. İnönü Üniversitesi Eğitim Fakültesi Dergisi, 15(3).

Wang, C.-K. and Lamb, C.W. Jr (1980). Foreign environmental factors influencing American consumers' predispositions toward European products. Academy of Marketing Science Journal, 8(4), 345-56.

Yoel Asseraf and Aviv Shoham, (2016). The "tug of war" model of foreign product purchases. European Journal of Marketing, 50(3/4), $550-574$. 